\title{
Investigation of Factors Affecting Mud Cuttings Transport in Slimhole Well Drilling
}

\author{
Phuc Kieu ${ }^{1,2}$, Quang Khanh Do ${ }^{1,2, *}$ \\ ${ }^{1}$ Ho Chi Minh City University of Technology (HCMUT), 268 Ly Thuong Kiet Street, District 10, Ho Chi Minh City, Vietnam. \\ ${ }^{2}$ Vietnam National University-Ho Chi Minh City (VNU-HCM), Linh Trung Ward, Thu Duc District, Ho Chi Minh City, Vietnam. \\ "Corresponding Author: ORCID: 0000-0003-2872-5743;
}

\begin{abstract}
Mud cuttings transport plays a very important role for the well drilling plan and operation. Especial for slimhole well drilling, the efficient removal of mud cuttings from drilled wells is considered a necessity for the success of the well drilling plan operation. However, there are still a little limited number of works relating to the mud cuttings transport in slimhole wells. In this article, two models developed from empirical approaches, namely Larsen's model and Rubiandini's model, were employed to consider the mud cuttings transport in slimhole well drilling. The effects of various drilling factors to the minimum flow velocity and flow rate required for an effective mud cuttings transport were investigated through simulation scenarios of case studies. The calculations from two empirical models showed that both models have the same trend for the minimum flow velocity and flow rate required for the transportation of mud cuttings with drilling parameters, such as rate of penetration (ROP), mud weight (MW), mud rheology, etc. Furthermore, several recommendations on how to achieve better mud cuttings transport are proposed from the obtained simulation results when using Larsen's and Rubiandini's models for calculating the critical mud flow rates in slimhole well drilling.
\end{abstract}

Keywords: Mud cuttings transport, Empirical models, Drilling parameters, Slimhole well drilling.

\section{INTRODUCTION}

The challenges for the petroleum and geothermal industry is to come up with a strategy to maximize the efficiency of exploration, drilling and production. The exploration and drilling of new wells are actually very expensive. These costs account for $30 \%$ to $70 \%$ of the cost of initial field development investment (Zhu T. and Carroll H.B.; Do et al., 2010) $[1,2]$. On the other hand, due to the current market fluctuations, if companies continue to develop strongly and stably, the problem is that the initial investment capital and operating costs must be reduced. One of the solutions that is being directed to this problem is to properly apply the slimhole drilling technology which permits effective cost reduction.

Slimhole drilling wells are drilled wells optimally reduced in size of casing levels. A slimhole well is a well type in which its borehole size is significantly smaller than the usual borehole size. It is generally less than 6 inches in diameter (Do et al. 2010) [2]. Also according to another definition extracted that wells with the size of casings less than 6 inches in diameter accounting for $90 \%$ or more are called slimhole wells (Michat Kruszewski et al. 2017) [3]. Or another interpretation from the study of the drilling process of slimhole wells classified the wells with the smallest diameter of casing diameter smaller than 7 inches as slimhole wells (Abdirisak A. Osman et al. 2015) [4]. In brief, although there are many different definitions for slimhole wells, for simplicity we can understand that the wells have been simplified in casing class and have a much smaller borehole diameter than regular wells are called slimhole wells. Below is an example of comparing diameter classes of slimhole and conventional wells (Fig. 1).

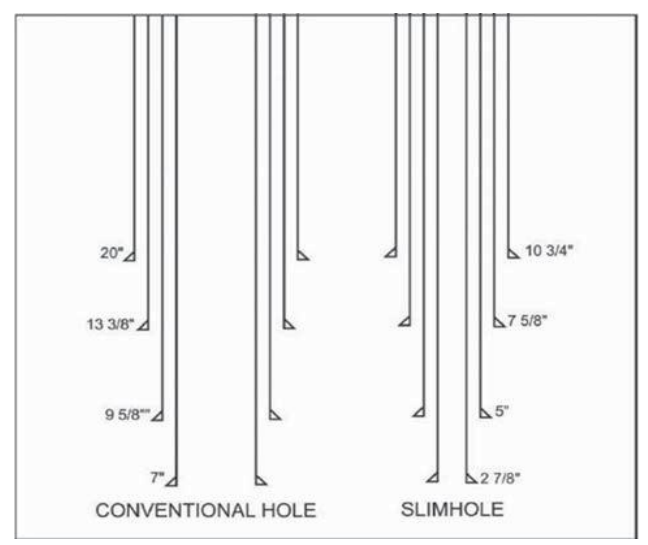

Fig. 1. Comparison of diameter of slimhole and conventional wells $[2,4]$.

To ensure the success of drilling plan and operations, one of the most important subjects is the mud cuttings transport into the well from the bottom-hole to the well surface (Ranjbar, 2010; Khanh et al., 2020) [5, 6]. Especially, for slimhole wells having much smaller borehole diameters, the mud cuttings transport in drilling is more and more important. In this article, two empirical models of Larsen and Rubiandini were employed to consider the mud cuttings transport in slimhole well drilling. Next, the effects of various drilling parameters as the rate of penetration (ROP), mud weight (MW), mud rheology, etc. to the minimum flow velocity and flow rate required for an effective mud cuttings transport were 
investigated through simulation scenarios of case studies. Finally, several recommendations on how to achieve better mud cuttings transport are proposed from the obtained simulation results when using Larsen's and Rubiandini's models for calculating the critical mud flow rates in slimhole well drilling.

\section{CALCULATING MODELS}

Many empirical models or correlations to estimate the slip velocity of cutting particles have been proposed rotary drilling. Among them, two empirical Larsen's and Rubiandini's models have used popularly for the drilling plan and operation.

\section{II.I Larsen's empirical model}

Based on a large number of empirical studies, Larsen (1997) focused on cutting size, inclination angle and mud weight of drill significantly affecting the transport of drilling cutting in directional and horizontal wells. The minimum velocity of $\mathrm{V}_{\text {min }}$ drilling mud is the total velocity of $\mathrm{V}_{\text {cut }}$ and slip velocity $\mathrm{V}_{\text {slip }}$ (Larsen et al., 1997) [7].

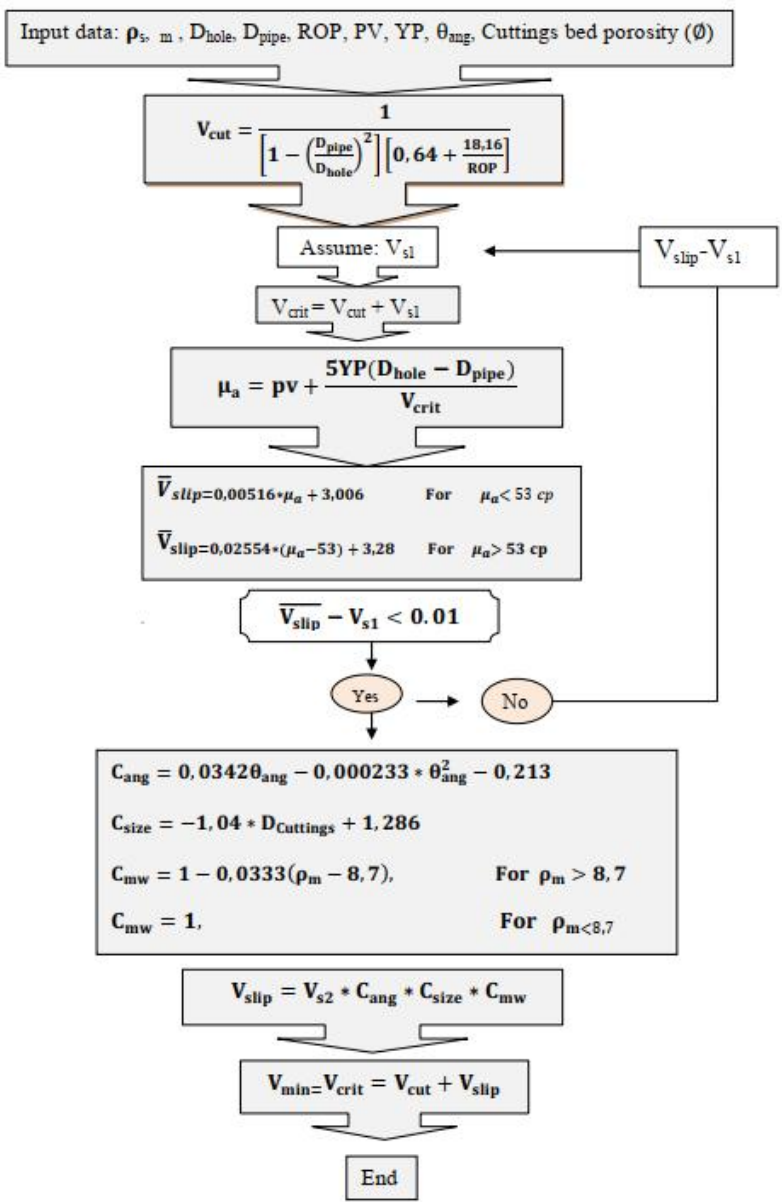

Fig. 2. Flowchart for calculating the velocity of drilling mud transport from Larsen's model $[5,6]$.

\section{II.II Rubiandini's empirical model}

Rubiandini (1999) presented a new equation to estimate the minimum speed of drilling mud for transporting cutting in inclined wells to horizontal wells. He believes that the drilling mechanism cutting transport is affected mainly by mud weight, inclination angle and rotation speed of RPM. Therefore, the correction factors for these parameters play a major role in his model (Rubiandini, 1999 ) [8].

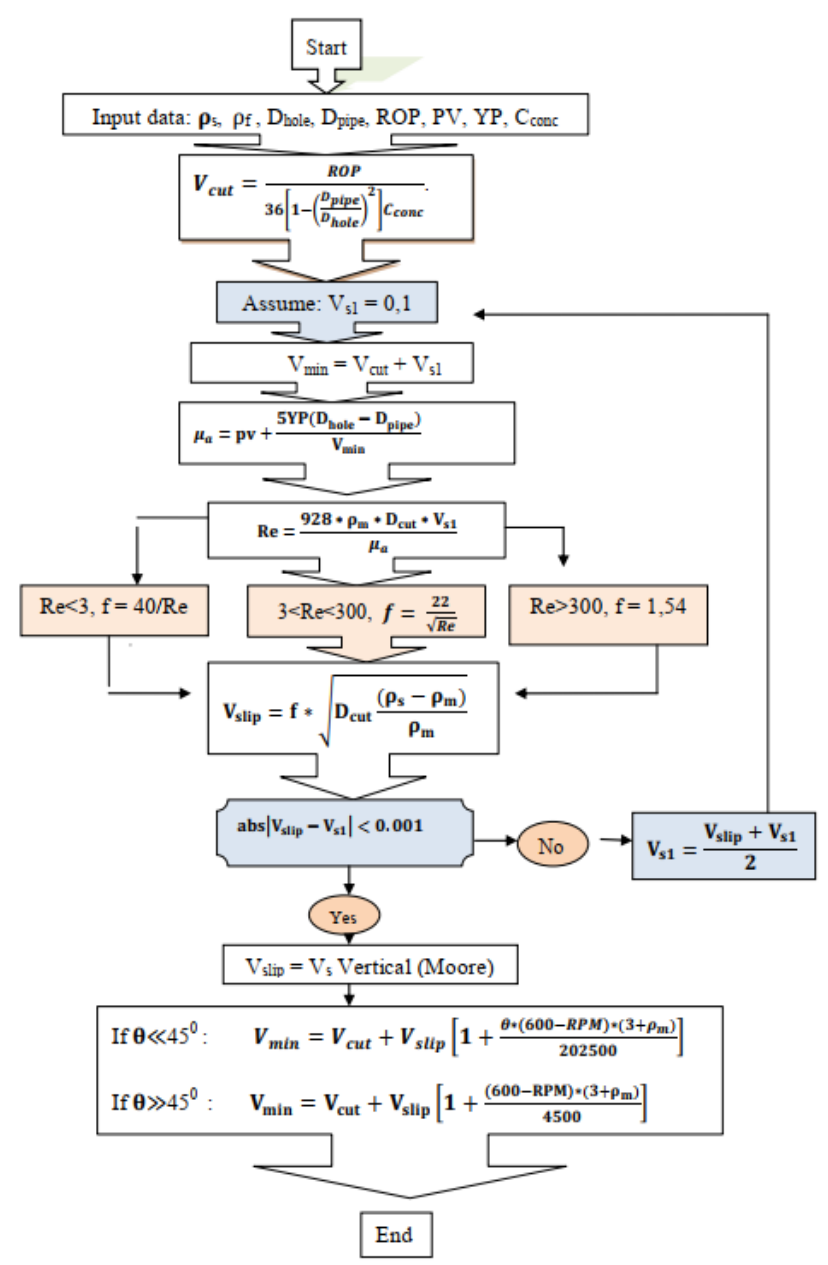

Fig. 3. Flowchart for calculating the velocity of drilling mud transport from Rubiandini's model $[5,6]$.

\section{CASE STUDY ON MUD CUTTINGS TRANSPORT FOR SLIMHOLE WELL DRILLING}

\section{III.I Input data}

In this work, input data including borehole and drillstring data for the slimhole well drilling considered are shown in the Table 1 and 2.

Table 1. Borehole Data [4]

\begin{tabular}{|c|c|c|c|}
\hline \multicolumn{4}{|c|}{ Borehole Data } \\
\hline & OD (in) & ID (in) & MD (ft) \\
\hline Casing & 7 & 6.250 & 14500.00 \\
\hline Open hole & & 6.250 & 16000.00 \\
\hline
\end{tabular}


Table 2. Drillstring Data [4]

\begin{tabular}{|c|c|c|c|}
\hline \multicolumn{4}{|c|}{ Drillstring Data } \\
\hline & Lengh (ft) & OD (in) & ID (in) \\
\hline Drill pipe & 15508.50 & 4.000 & 3.240 \\
\hline Heavy weight & 120.00 & 4.500 & 2.750 \\
\hline Jar & 32.00 & 4.750 & 2.250 \\
\hline Heavy weight & 305.00 & 4.500 & 2.750 \\
\hline Sub & 3.00 & 4.440 & 1.440 \\
\hline MWD & 22.50 & 4.750 & 1.600 \\
\hline Stabilizer & 5.00 & 3.250 & 1.500 \\
\hline Sub & 3.00 & 4.440 & 1.440 \\
\hline Bit & 1.00 & 5.875 & \\
\hline \multicolumn{4}{|c|}{}
\end{tabular}

Moreover, predictive calculations of on mud cuttings transport are performed with mud and drilling parameters as shown in the Table 3.

Table 3. Data of mud and drilling parameters [4].

\begin{tabular}{|l|c|}
\hline \multicolumn{2}{|c|}{ Mud and drilling parameters } \\
\hline Mud weight (ppg) & 11.3 \\
\hline Plastic viscosity PV (cp) & 12 \\
\hline Yield point YP (lbf/100ft $\left.{ }^{2}\right)$ & 21 \\
\hline Cuttings diameter $\mathrm{D}_{\text {cutt }}(\mathrm{in})$ & 0.125 \\
\hline Rotary speed RMP (rpm) & 50 \\
\hline Rate of penetration ROP $(\mathrm{ft} / \mathrm{hr})$ & 25 \\
\hline
\end{tabular}

\section{III.II Results and discussion on factors affecting mud cuttings transport}

The study will take into account the calculation and adjustment on the minimum flow velocity $\mathrm{V}_{\min }$ and flow rate $\mathrm{Q}_{\text {min }}$ of mud cuttings transport for the considered slimhole well from both two Larsen's and Rudi's models. Using computer programs, predictive curves are established based on the experimental data set (Ranjbar, 2010; Khanh et al., 2020), [5, 6].

In the simulation scenarios, the variables are used for both Larsen's and Rubiandini's models and only one of these parameters is varied in each simulation. Therefore, the effects of drilling variable parameters, such as rate of penetration (ROP), drilling mud weight (MV), mud rheology, etc. to the minimum flow velocity $\mathrm{V}_{\text {min }}$ and flow rate $\mathrm{Q}_{\min }$ required for mud cuttings transport will perform through simulation scenarios.

\section{III.II.1 Larsen's model}

\section{1) Effect of rate of penetration $R O P$ on $V_{\min }$ and $Q_{\min }$}

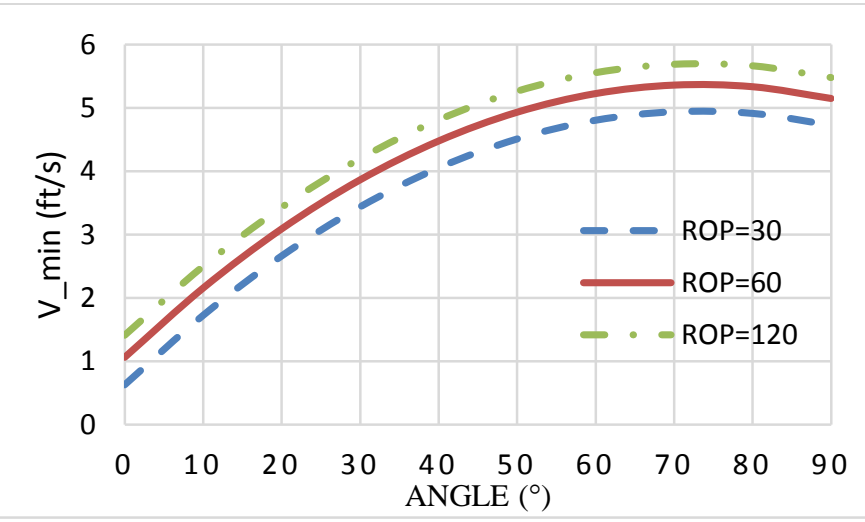

Fig. 4. Flow velocity vs. angle of inclination with variation of ROP from Larsen's model.

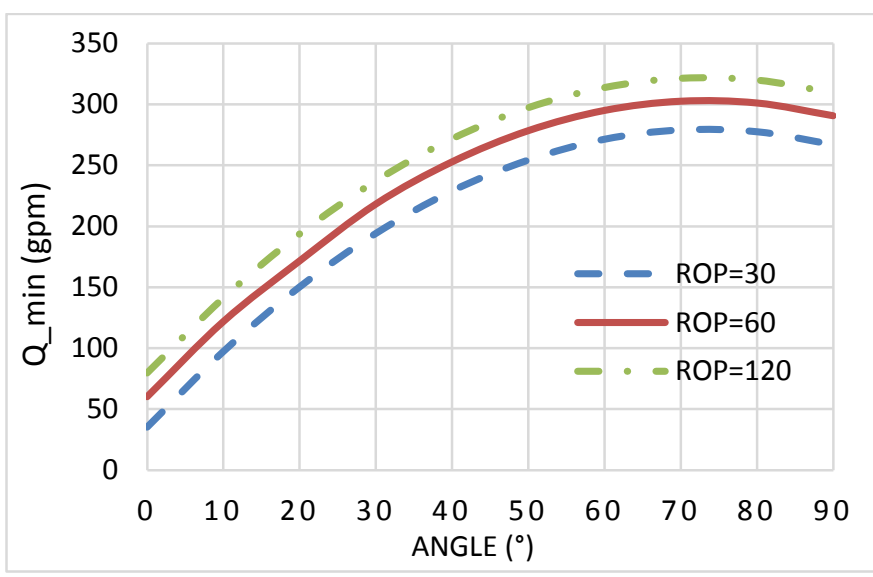

Fig. 5. Flow rate vs. angle of inclination with variation of ROP from Larsen's model.

From the two graphs above (Fig. 4, 5), when increasing ROP, both of $\mathrm{V}_{\text {min }}$ and $\mathrm{Q}_{\text {min }}$ increase clearly for wells with an inclination less than $70^{\circ}$ then decrease slightly for wells with an inclination greater than $70^{\circ}$.

\section{2) Effect of driling mud weight on $V_{\min }$ and $Q_{\min }$}

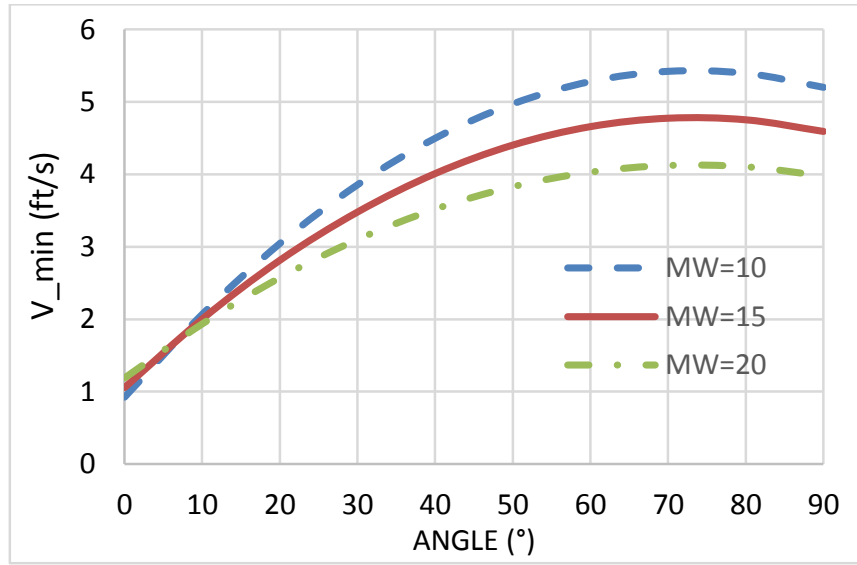

Fig. 6. Flow velocity vs. angle of inclination with variation of MW from Larsen's model. 


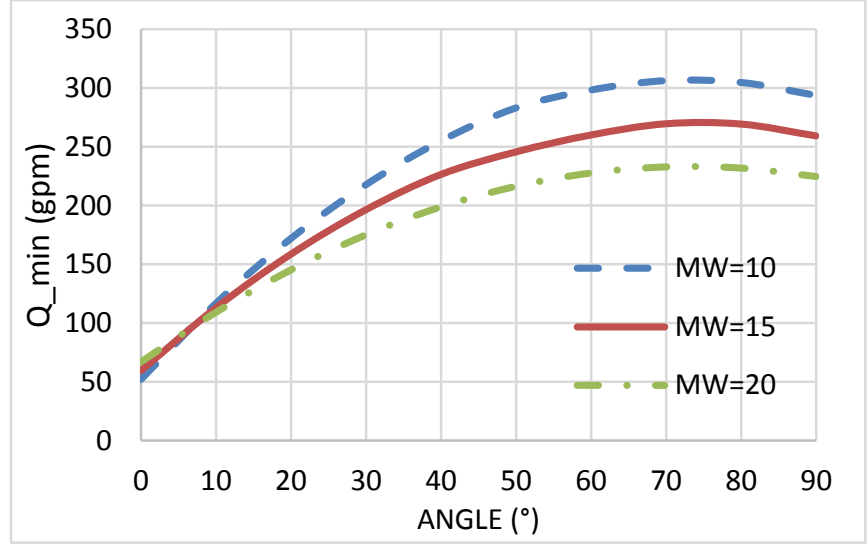

Fig. 7. Flow rate vs. angle of inclination with variation of MW from Larsen's model.

From the two graphs above (Fig. 6, 7), when the angle of inclination is less than $10^{\circ}$, increasing the drilling mud weight does not affect to both $\mathrm{Q}_{\min }$ and $\mathrm{V}_{\text {min }}$. However, when the angle of inclination is greater than $10^{\circ}$, increasing mud weight will reduce both $\mathrm{V}_{\min }$ and $\mathrm{Q}_{\min }$.

\section{3) Effect of mud rheology on $V_{\min }$ and $Q_{\min }$}

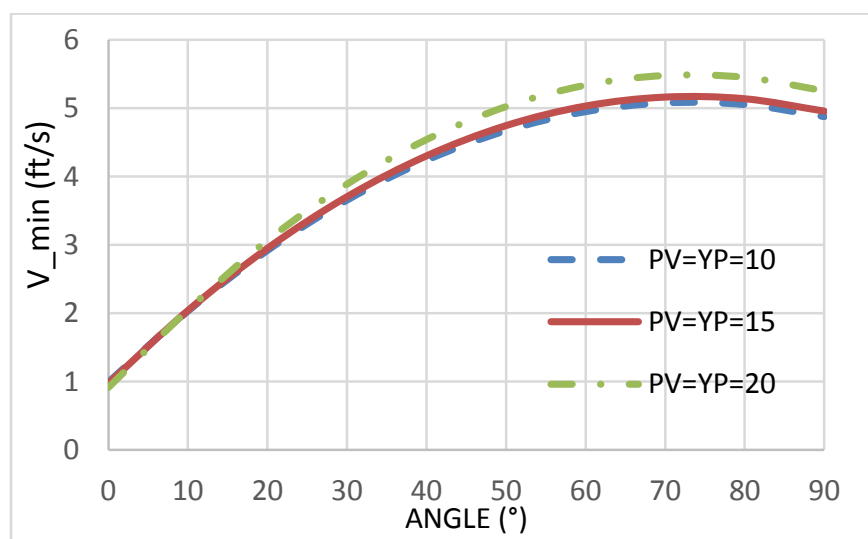

Fig. 8. Flow velocity vs. angle of inclination with variation of mud rheology from Larsen's model.

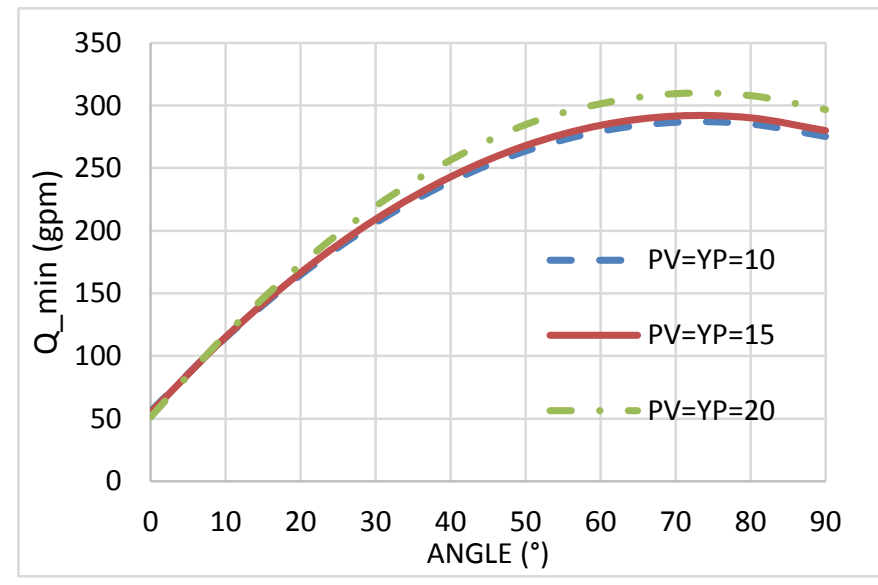

Fig. 9. Flow rate vs. angle of inclination with variation of mud rheology from Larsen's model.
From the two graphs above (Fig. 8, 9), similary to the case of mud weight when the angle of inclination is less than $10^{\circ}$, increasing the mud rheology does not affect to both $\mathrm{Q}_{\min }$ and $\mathrm{V}_{\text {min. }}$. However, when the angle of inclination is greater than $10^{\circ}$, increasing mud rheology will increase both $\mathrm{V}_{\min }$ and $\mathrm{Q}_{\min }$.

\section{III.II.2 Rubiandini’s model}

\section{1) Effect of rate of penetration $R O P$ on $V_{\min }$ and $Q_{\min }$}

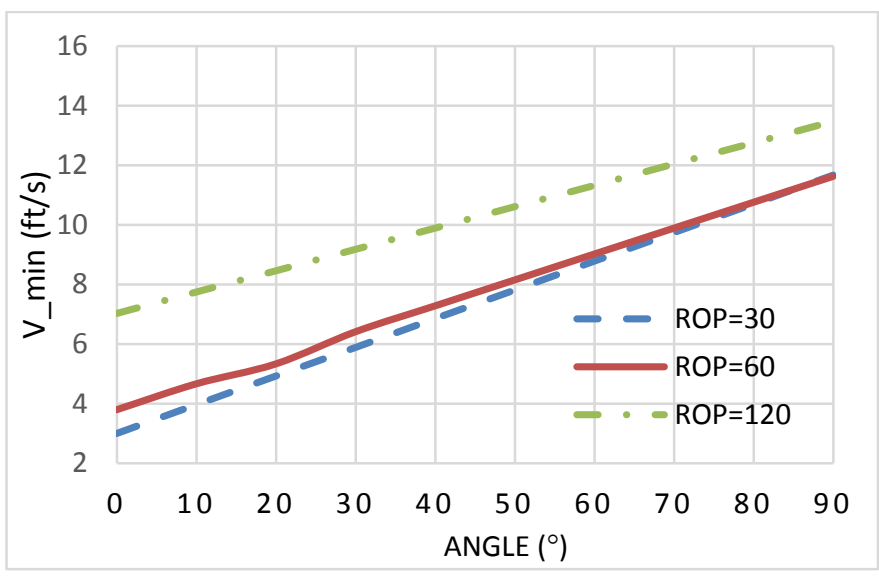

Fig. 10. Flow velocity vs. angle of inclination with variation of ROP from Rubi's model.

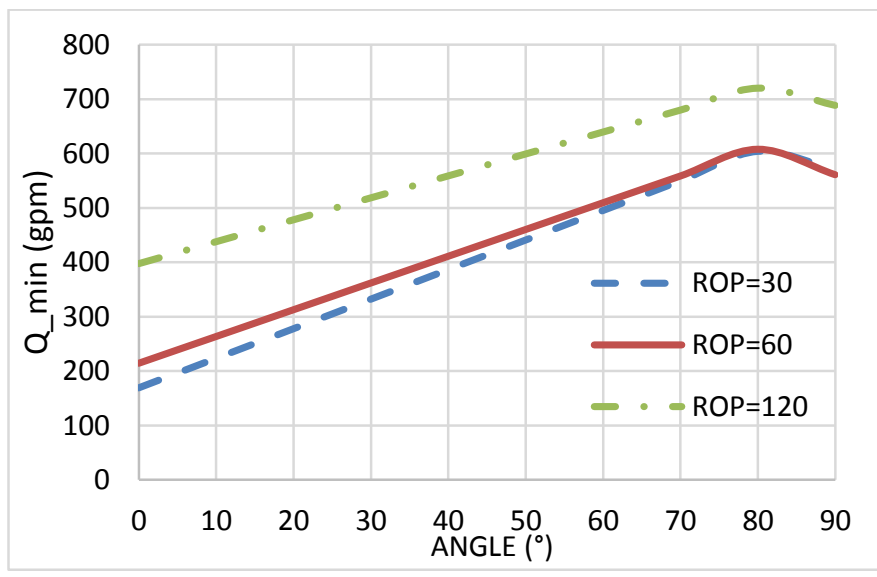

Fig. 11. Flow rate vs. angle of inclination with variation of ROP from Rubi's model.

At Fig. 10 when increasing ROP, the minimum flow velocity $\mathrm{V}_{\min }$ increases. Especially, an increase in ROP from 30 to 60 $\mathrm{ft} / \mathrm{hr}$ will not increase $\mathrm{V}_{\text {min }}$ clearly for wells with an angle of inclination above $70^{\circ}$.

However, at Fig. 11 when increasing ROP, the minimum circulating flow rate $Q_{\min }$ increases for wells with an inclination angle less than $80^{\circ}$ and then decreases gradually for wells with an inclination angle in the range from $80^{\circ}$ to $90^{\circ}$. Furthermore, an increase in ROP from 30 to $60 \mathrm{ft} / \mathrm{hr}$ will also not increase $\mathrm{V}_{\text {min }}$ clearly for wells with an angle of inclination above $70^{\circ}$. 


\section{2) Effect of driling mud weight on $V_{\min }$ and $Q_{\min }$}

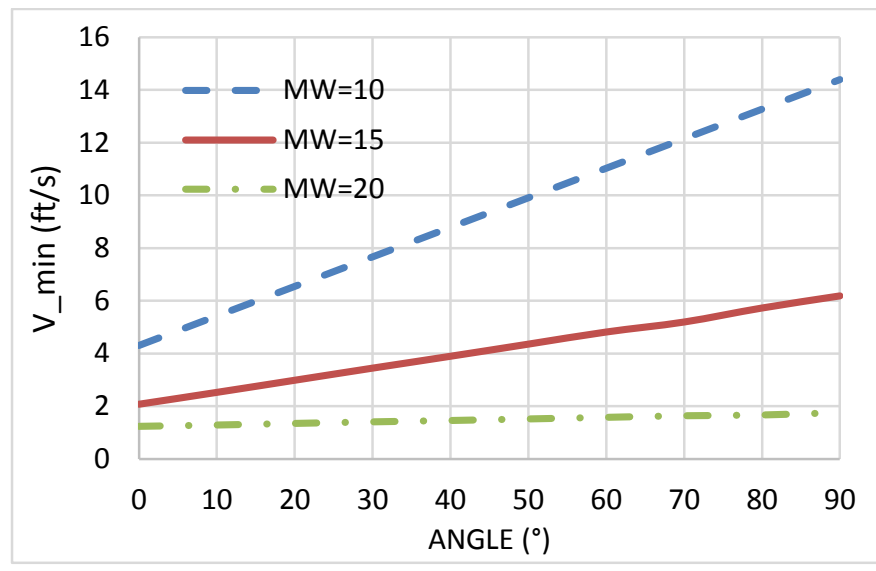

Fig. 12. Flow velocity vs. angle of inclination with variation of MV from Rubi's model.

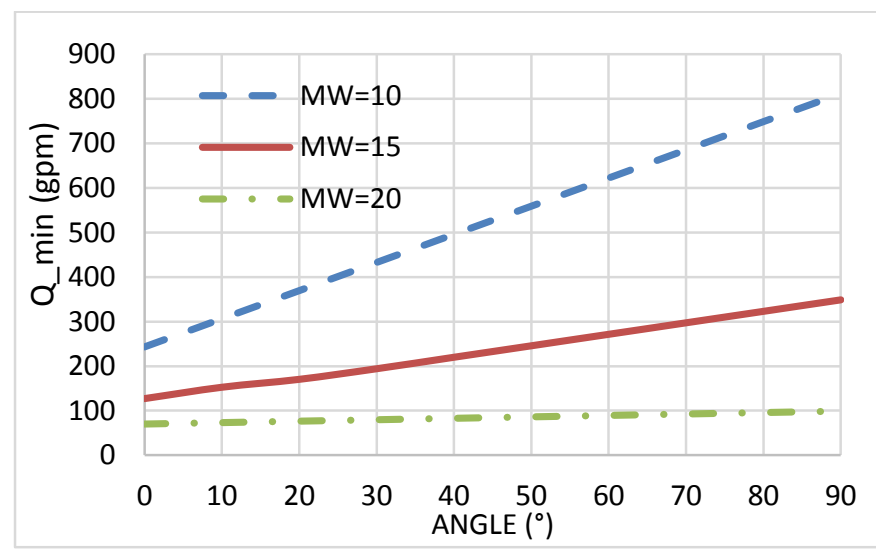

Fig. 13. Flow rate vs. angle of inclination with variation of MV from Rubi's model.

From the two graphs above (Fig. 12, 13), when increasing mud weight, both of $\mathrm{V}_{\min }$ and $\mathrm{Q}_{\min }$ reduce. However, for the mud weight of 20 ppg both $\mathrm{V}_{\min }$ and $\mathrm{Q}_{\min }$ are almost independent on the inclination angle.

\section{3) Effect of mud rheology on $V_{\min }$ and $Q_{\min }$}

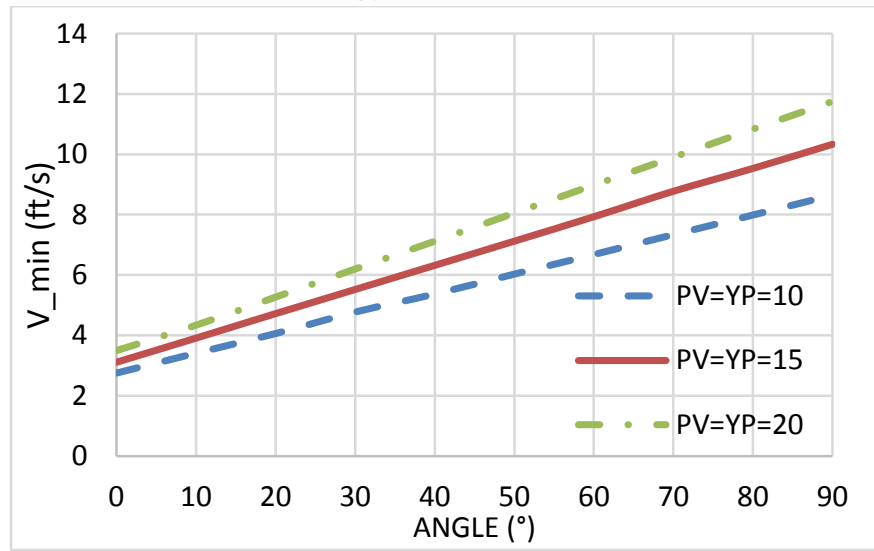

Fig. 14. Flow velocity vs. angle of inclination with variation of mud rheology from Rubi's model.

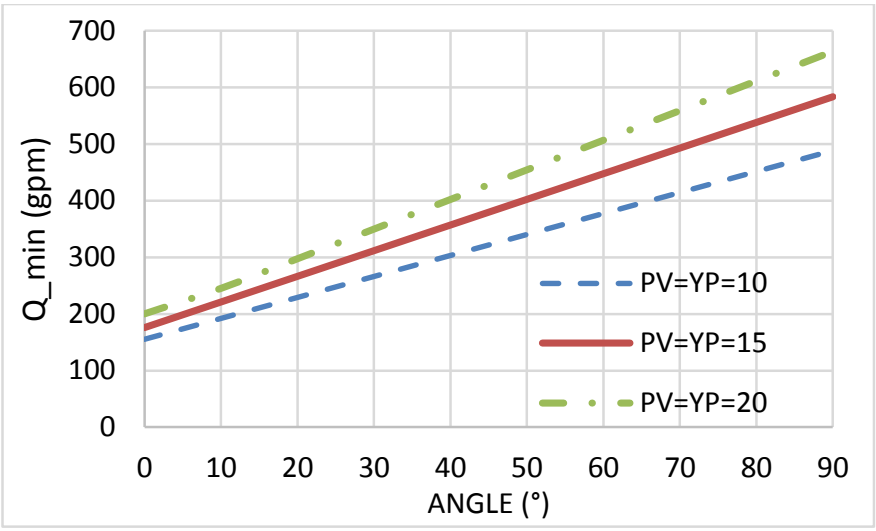

Fig. 15. Flow rate vs. angle of inclination with variation of mud rheology from Rubi's model.

From the two graphs above (Fig. 14, 15), increasing the drilling mud rheology including plastic viscosity PV and yield point $\mathrm{YP}$ will increase both $\mathrm{V}_{\min }$ and $\mathrm{Q}_{\min }$ of mud cutings transport process.

\section{CONCLUSIONS}

The calculation and modeling of mud cuttings transport are very important to increase drilling efficiency and minimize serious risks for slimhole well drilling due the smaller dimension of slimhole wells comparing to conventional wells.

The models of Larsen and Rubiandini, which are modeled using sample data from the actual drilling situations, were employed to determine the required minimum flow velocity and flow rate of mud cuttings transport in slimhole well drilling.

The investigation of factors affecting mud cuttings transport capacity of drilling mud such as rate of penetration (ROP), drilling mud weight (MW), mud rheology, etc. from these two models were carried out and analysed for the considered slimhole well drilling. From the obtained results, several recommendations on the mud cuttings transport for slimhole well drilling are proposed as follows:

- As the rate of penetration (ROP) increases, the number of cutting particles will be created more and more. Therefore, both two values of the required minimum flow velocity and flow rate of drilling mud also increased. However, for slimhole wells with an inclination angle greater than $75-80^{\circ}$, the required minimum flow rate may decrease slightly.

- Increasing the drilling mud weight (MW) almost does not affect to mud cuttings transport for slimhole wells with an inclination angle less than $10^{\circ}$. However, when the inclination angle is greater than $10^{\circ}$, it will reduce to both the minimum flow velocity and flow rate required for mud cuttings transport. 
- Similary to the case of mud weight, increasing the mud rheology including plastic viscosity PV and yield point YP does not affect to mud cuttings transport for slimhole wells with the inclination angle less than $10^{\circ}$. However, when the angle of inclination is greater than $10^{\circ}$, it will increase both the minimum flow velocity and flow rate required for mud cuttings transport.

\section{NONCLEMENTATION}

$\rho_{\text {cut }}=$ Density of cuttings, $(\mathrm{lbm} / \mathrm{gal}),\left(\mathrm{kg} / \mathrm{m}^{3}\right)$

$\rho_{\mathrm{m}}=$ Density of drilling fluid, $(\mathrm{lbm} / \mathrm{gal}),\left(\mathrm{kg} / \mathrm{m}^{3}\right)$

MW = Mud weight, (lbm/gal)

$\mathrm{ECD}=$ Equivalent circulating density

$\mathrm{C}_{\mathrm{i}}=$ Correction factor for angle, (dimensioless)

$\mathrm{C}_{\mathrm{conc}}=$ Cuttings concentration, $(\%)$

$\mathrm{C}_{\mathrm{mw}}=$ Correction factor for mud density, (dimensionless)

$\mathrm{C}_{\mathrm{RPM}}=$ Correction factor for $\mathrm{rpm},($ dimensionless $)$

$\mathrm{C}_{\text {size }}=$ Correction factor for cuttings size (dimensionless)

$\mathrm{D}_{\text {hole }}=$ Hole diameter, (inch), (m)

$\mathrm{D}_{\text {pipe }}=$ Pipe diameter, (inch), $(\mathrm{m})$

$\mathrm{f}=$ Friction factor, (dimensionless)

$\mathrm{PV}=$ Plastic viscosity $(\mathrm{cP}),\left(\mathrm{Pa}^{*} \mathrm{~s}\right)$

$\operatorname{Re}=$ Reynolds number, (dimensionless)

ROP $=$ Rate of penetration, $(\mathrm{ft} / \mathrm{hrs}),(\mathrm{m} / \mathrm{hrs})$

$\mathrm{RPM}=$ Drill-pipe rotation per min

$\mathrm{V}_{\text {cut }}=$ Cuttings velocity, $(\mathrm{ft} / \mathrm{s}),(\mathrm{m} / \mathrm{s})$

$\mathrm{V}_{\text {crit }}=$ Critical velocity, $(\mathrm{ft} / \mathrm{s}),(\mathrm{m} / \mathrm{s})$

$\mathrm{V}_{\min }=$ Minimum velocity, $(\mathrm{ft} / \mathrm{s}),(\mathrm{m} / \mathrm{s})$

$\mathrm{V}_{\text {slip }}=$ Slip velocity, $(\mathrm{ft} / \mathrm{s}),(\mathrm{m} / \mathrm{s})$

$\mathrm{Q}_{\min }=$ Minimum flow rate, $(\mathrm{gpm}),(1 / \mathrm{s})$

$\mathrm{YP}=$ Yield point $\left(\mathrm{lbf} / 100 \mathrm{ft}^{2}\right),(\mathrm{Pa})$

$\theta=$ Angle of inclination of wellbore from vertical (degrees)

$\rho_{\mathrm{m}}=$ Density of mud, $(\mathrm{lbm} / \mathrm{gal}),\left(\mathrm{kg} / \mathrm{m}^{3}\right)$

$\rho_{\mathrm{f}}=$ Density of fluid, $(\mathrm{lbm} / \mathrm{gal}),\left(\mathrm{kg} / \mathrm{m}^{3}\right)$

$\rho_{\mathrm{s}}=$ Density of cuttings, $(\mathrm{lbm} / \mathrm{gal}),\left(\mathrm{kg} / \mathrm{m}^{3}\right)$

$\mu_{\mathrm{a}}=$ Apparent viscosity $(\mathrm{cP}),\left(\mathrm{Pa}^{*} \mathrm{~s}\right)$

\section{ACKNOWLEDGEMENTS}

Authors would like to thank a lot all members of Division of Modelling and Simulation, Faculty of Geology and Petroleum Engineering, HoChiMinh University of Technology (HCMUT), Vietnam National University - HoChiMinh City (VNU-HCM) for their help and discussion. We acknowledge the support of time and facilities from Ho Chi Minh City University of Technology (HCMUT), VNU-HCM for this study. This research is funded by Ho Chi Minh University of Technology (HCMUT), VNU-HCM, under grant number BKSDH-2020-1770508.

\section{REFERENCES}

[1] Zhu T. and Carroll H.B. (1994), A Review of Slimhole Drilling, U.S. Department of Energy, Bartlesville Project Office, Oklahoma, Septemper 1994.

[2] Do Q.K., Doan T., Hoang T.Q., Nguyen T.T.T., Tran T. (2019) Potential Application of Slimhole Drilling Technology to Geothermal Wells in Vietnam. In: Randolph M., Doan D., Tang A., Bui M., Dinh V. (eds) Proceedings of the 1st Vietnam Symposium on Advances in Offshore Engineering. Lecture Notes in Civil Engineering, vol 18. Springer, Singapore. VSOE 2018.

[3] Michał Kruszewski and Sverrir Thorhallsson (2017), Slimhole well casing design for high-temperature geothermal exploration and reservoir assessment, AGH Drilling, Oil, Gas. Vol. No2, 2017.

[4] Abdirisak A. Osman (2015), Analysis of Slimhole drilling operations, Master thesis, University of Stavanger, 2015.

[5] Ranjbar R. (2010), Cutting transport in inclined and horizontal well, Master's Thesis. Stavange, 102 p, 2010.

[6] Khanh D.Q., Dat T.T.T., Phuc K., Huong T.T.M., Quang H.T. (2020), Modeling on Cuttings Transport in Inclined and Horizontal Well Drilling. In: HaMinh C., Dao D., Benboudjema F., Derrible S., Huynh D., Tang A. (eds), Innovation for Sustainable Infrastructure. Lecture Notes in Civil Engineering, vol 54. Springer, Singapore. CIGOS 2019.

[7] Larsen T.I., Pilehvari A.A., Azar, J.J. (1997), Development of a new cuttings-transport model for high-angle wellbores including horizontal wells, Society of Petroleum Engineers. Document ID: SPE25872-PA, 1997.

[8] Rudi Rubiandini R.S. (1999), Equation for mud estimating minimum rate for cuttings transport in an inclined-until-horizontal well, Society of Petroleum Engineers, Document ID: SPE-57541-MS, 1999. 